Brit.J. vener. Dis. (1963), 39, 105.

\title{
EPIDEMIOLOGY OF GONORRHOEA
}

\section{A DEPARTURE FROM THE TYPICAL INCIDENCE PICTURE*}

\author{
BY
}

\author{
R. S. MORTON
}

Royal Hospital, Sheffield

A sudden and marked rise followed by an equally sudden and marked fall in the incidence of gonorrhoea in any area constitutes such a departure from the recognized pattern of events in England and Wales as to call for an explanation. Such a variation occurred in recent years in Barnsley and Doncaster. This report is an attempt to explain the phenomenon by comparing the epidemiological factors at work in these towns, with those found in Sheffield and Rotherham.

\section{General Considerations}

Two definite trends are discernible in the area (Table I). The clinics in Sheffield and Rotherham follow the pattern in the country as a whole. Barnsley and Doncaster show around a 150 per cent. rise in 1959 with an almost equal fall in 1960 and 1961 respectively. General factors (e.g. methods of diagnosis, clinic times, facilities, and staff) which might influence these rates have altered very little.

\section{TABLE I}

TOTAL INCIDENCE OF GONORRHOEA IN ENGLAND AND WALES WITH RATES IN THE CLINICS OF THE AREAS CONCER NED, 1955-61

Female infections are shown in brackets

\begin{tabular}{c|c|c|c|c|c}
\hline \multirow{2}{*}{ Year } & $\begin{array}{c}\text { England } \\
\text { and } \\
\text { Wales }\end{array}$ & Sheffield & $\begin{array}{c}\text { Rother- } \\
\text { ham }\end{array}$ & Barnsley & Doncaster \\
\cline { 2 - 6 } & $\mathbf{M}(\mathrm{F})$ & $\mathbf{M}(\mathrm{F})$ & $\mathbf{M}(\mathrm{F})$ & $\mathbf{M}$ F) \\
\hline 1955 & 17,845 & $122(30)$ & $14 \quad 2)$ & $11(1)$ & $86(21)$ \\
\hline 1956 & 20,388 & $87(18)$ & $11(2)$ & $23(4)$ & $77(22)$ \\
\hline 1957 & 24,381 & $188(28)$ & $22(5)$ & $26(4)$ & $74(13)$ \\
\hline 1958 & 27,887 & $294(51)$ & $41(14)$ & $45(6)$ & $81(16)$ \\
\hline 1959 & 31,344 & $331(55)$ & $41(6)$ & $111(24)$ & $212(46)$ \\
\hline 1960 & 33,770 & $320(68)$ & $55(9)$ & $48(8)$ & $225(62)$ \\
\hline 1961 & 37,026 & $450(102)$ & $95(18)$ & $25(6)$ & $101(30)$ \\
\hline
\end{tabular}

* Short paper read to the M.S.S.V.D., November 30, 1962.
We must therefore look elsewhere for an explanation.

\section{Population and Racial Factors}

The population served by the clinics has increased slightly over the years covered and this may be considered somewhat selective, as young men are now no longer obliged to do national service with the Forces. The main influence in this direction, however, has been more one of quality than of quantity. As elsewhere the area has been subject to the immigration of large numbers of unattached males. Thus, in Sheffield in 1961, the male immigrant population was estimated to be nearing 8,000 . Less than half the total were West Indians; Adenese, Pakistanis, and Somalis, i.e. Moslems, have always predominated, with Indians, Chinese, and Irish less numerous. The great majority of these men live and work on the north-east or Rotherham side of Sheffield and there is little doubt that their presence there contributes to the parallel findings as regards infection in the two places. Table II (overleaf) shows the steady rise of gonorrhoea in immigrants in Sheffield from 20 per cent. of the total in 1955 to 80 per cent. in 1961. Comparable figures for Rotherham are 0 per cent. and 55 per cent. Immigration in these two places continues to rise.

How does this compare with Barnsley and Doncaster? Coloured immigrants have been almost unknown in Barnsley. In 1958-1959 however, Irish labour was employed on the outskirts of the town at temporary opencast coal workings. These men contributed to the gonorrhoea rise, forming, in the peak year of 1959, 17 per cent. of all male infections, and in the year preceding the peak, immigrants formed 46 per cent. of the total male infections. With the closing of the workings in 1960, these men left the town and this has been followed by a marked reversal of incidence levels. In Doncaster, Irish and Commonwealth immigrant populations increased steadily, reaching a peak in 1959 and 1960 when two 
TABLE II

MALE CASES OF GONORRHOEA-U.K.-BORN AND IMMIGRANTS, 1955-61

\begin{tabular}{|c|c|c|c|c|c|c|c|c|c|c|c|c|c|}
\hline & rea & & & rigi & & & 1955 & 1956 & 1957 & 1958 & 1959 & 1960 & 1961 \\
\hline \multirow[t]{2}{*}{ Sheffield } & \multirow[t]{2}{*}{$\cdots$} & \multirow[t]{2}{*}{$\cdots$} & $\begin{array}{l}\text { U.K.-Born } \\
\text { Immigrants }\end{array}$ & 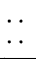 & 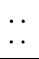 & $\begin{array}{l}\cdots \\
\cdots\end{array}$ & $\begin{array}{l}70 \\
22\end{array}$ & $\begin{array}{l}41 \\
28\end{array}$ & $\begin{array}{r}57 \\
103\end{array}$ & $\begin{array}{r}80 \\
163\end{array}$ & $\begin{array}{l}106 \\
170\end{array}$ & $\begin{array}{r}84 \\
168\end{array}$ & $\begin{array}{r}75 \\
273\end{array}$ \\
\hline & & & Total $\ldots$ & . & $\cdots$ & $\cdots$ & 92 & 69 & 160 & 243 & 276 & 252 & 348 \\
\hline \multirow{2}{*}{\multicolumn{2}{|c|}{ Rotherham . . }} & \multirow[t]{2}{*}{$\cdots$} & $\begin{array}{l}\text { U.K.-Born } \\
\text { Immigrants }\end{array}$ & $\cdots$ & 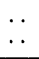 & $\ddot{*}$ & 12 & 9 & $\begin{array}{r}15 \\
2\end{array}$ & $\begin{array}{r}20 \\
7\end{array}$ & $\begin{array}{l}21 \\
14\end{array}$ & $\begin{array}{l}23 \\
23\end{array}$ & $\begin{array}{l}38 \\
39\end{array}$ \\
\hline & & & Total .. & . & $\cdots$ & $\cdots$ & 12 & 9 & 17 & 27 & 35 & 46 & 77 \\
\hline \multirow[t]{2}{*}{ Barnsley } & \multirow[t]{2}{*}{$\cdots$} & \multirow[t]{2}{*}{$\cdots$} & $\begin{array}{l}\text { U.K.-Born } \\
\text { Immigrants }\end{array}$ & . & $\ddot{x}$ & $\ddot{*}$ & $\begin{array}{l}7 \\
3\end{array}$ & $\begin{array}{r}16 \\
3\end{array}$ & $\begin{array}{r}19 \\
3\end{array}$ & $\begin{array}{l}25 \\
14\end{array}$ & $\begin{array}{l}74 \\
13\end{array}$ & $\begin{array}{r}33 \\
7\end{array}$ & $\begin{array}{r}21 \\
1\end{array}$ \\
\hline & & & Total .. & . & . & $\cdots$ & 10 & 19 & 22 & 39 & 87 & 40 & 22 \\
\hline \multirow[t]{2}{*}{ Doncaster . } & \multirow[t]{2}{*}{$\cdots$} & \multirow[t]{2}{*}{$\cdots$} & $\begin{array}{l}\text { U.K.-Born } \\
\text { Immigrants }\end{array}$ & $\begin{array}{l}\cdots \\
\cdots\end{array}$ & $\begin{array}{l}\cdots \\
\cdots\end{array}$ & $\begin{array}{l}\cdots \\
\cdots\end{array}$ & $\begin{array}{r}61 \\
4\end{array}$ & $\begin{array}{r}53 \\
2\end{array}$ & $\begin{array}{l}47 \\
14\end{array}$ & $\begin{array}{l}53 \\
12\end{array}$ & $\begin{array}{r}124 \\
42\end{array}$ & $\begin{array}{r}112 \\
51\end{array}$ & $\begin{array}{l}49 \\
22\end{array}$ \\
\hline & & & Total . . & $\ldots$ & $\ldots$ & .. & 65 & 55 & 61 & 65 & 166 & 163 & 71 \\
\hline
\end{tabular}

local construction projects were in full swing. During the peak year of 1960 , immigrants contributed 45 per cent. of all male infections. With the completion of the work in late 1960 and early 1961, many left the town, and some who have stayed are believed to have forsaken promiscuity for a more settled arrangement.

Table II also shows a striking difference between Sheffield and Rotherham on the one hand and Barnsley and Doncaster on the other in relation to the actual incidence of infections in U.K.-born males. The number in Sheffield, and to a lesser extent in Rotherham, has altered little over the years compared with the explosive rises in Barnsley and Doncaster during the years of peak incidence. Indeed it should be pointed out that, in Sheffield in 1961, gonorrhoea was diagnosed more often in U.K.-born females than in U.K.-born males. The ratio was $82: 75$, another nineteen females being treated epidemiologically. How far these facts indicate different patterns of endogenous promiscuity in and around the individual towns concerned is not clear.

It is perhaps of interest in this regard to consider the illegitimacy rates. Although there have been no parallels or identifiable delayed parallels with gonorrhoea rates, there has been a general increase in all the areas concerned since 1958. With the exception of Rotherham, unusually high figures of over 5 per cent. have been reported for 1961 .

\section{Age and Sex}

Table III (opposite) shows infections grouped by age and sex. Sheffield and Rotherham are characterized by an increasing preponderance of cases in females aged 15-19 years. In Barnsley and Doncaster this also happened during the peak incidence years. In Barnsley the trend was reversed with the departure of the immigrants. A similar fall in Doncaster cannot be expected before 1962 as the epidemic there is a year behind that in Barnsley. For the first threequarters of 1962 the Doncaster figures are 15-19 years $-6 ; 20-24$ years $-8 ; 25$ years and over-9. This fall in the proportion of teenagers, although not so dramatic as at Barnsley, is hopeful. The Street Offences Bill has been repeatedly used in Doncaster and it is hoped that this social medium will accelerate the recovery of control.

\section{Treatment}

Table IV (opposite) shows rising failure and relapse rates in the clinics concerned, and the re-infection rates are also shown; Doubtless these figures are subject to individual judgement as regards failure and re-infection. The routine penicillin dosage was 300,000 units of P.A.M. in the earlier years.

The Medical Research Council study (1961) has clearly shown the high incidence of relatively insensitive strains in the southern half of the West Riding of Yorkshire. At least 30 per cent. of strains required 0.25 units $/ \mathrm{ml}$. or more of penicillin during the latter half of 1959 and early part of 1960 . The work of testing the strains was carried out at the Public Health laboratories in Wakefield and Sheffield on behalf of the clinics at Barnsley and Sheffield. No sensitivity testing has been done at Rotherham. At Doncaster, Hilton (1959), using the disk method, showed that the in vitro concentrations of penicillin required to inhibit the majority [sic] of strains in 1958-59 was 0.25 units $/ \mathrm{ml}$. or more. He was later able to show, during a trial of Broxil therapy in 1959-1960, that 80 per cent. of his least sensitive strains, compared with 18 per cent. of his most sensitive strains, were among infections failing to respond or relapsing (Hilton, 1961). 
TABLE III

AGE GROUPS OF GONORRHOEA CASES, BY SEX, 1955-61

\begin{tabular}{|c|c|c|c|c|c|c|c|c|c|c|}
\hline \multirow{2}{*}{\multicolumn{3}{|c|}{ Area }} & \multirow{2}{*}{ Age (yrs) } & 1955 & 1956 & 1957 & 1958 & 1959 & 1960 & 1961 \\
\hline & & & & M (F) & $M(F)$ & M (F) & $M(F)$ & $M(F)$ & $M(F)$ & $M(F)$ \\
\hline \multirow{4}{*}{ Sheffield .. } & \multirow{4}{*}{.. } & \multirow{4}{*}{$\cdots$} & $15-19$ & $2(6)$ & $2(4)$ & $5 \quad(7)$ & $8(16)$ & $13(11)$ & $11(21)$ & $10 \quad(37)$ \\
\hline & & & $.20-24$ & $20 \quad(8)$ & 17 (9) & $44(10)$ & $60(18)$ & $68(17)$ & $54(23)$ & $84 \quad(38)$ \\
\hline & & & 25 and Over & $70(16)$ & $50 \quad(5)$ & $111(11)$ & $175(17)$ & $195(27)$ & $187(24)$ & $254 \quad(27)$ \\
\hline & & & Total .. & $92(30)$ & $69(18)$ & $160(28)$ & $243(51)$ & $276(55)$ & $252(68)$ & $348(102)$ \\
\hline \multirow{4}{*}{ Rotherham } & & \multirow{4}{*}{. } & $15-19$ & $-(-)$ & $1(0)$ & 0 (1) & 0 (1) & 1 (1) & $0 \quad$ (1) & (6) \\
\hline & & & $20-24$ & $3(-)$ & $2(1)$ & $5(3)$ & $4(5)$ & $10 \quad(1)$ & $10 \quad(3)$ & $17 \quad(7)$ \\
\hline & & & 25 and Over & 9 (2) & $6(1)$ & $12(1)$ & $23(8)$ & 24 (4) & $36 \quad(5)$ & $58 \quad(5)$ \\
\hline & & & Total ... & $12(2)$ & 9 (2) & $17 \quad(5)$ & $27(14)$ & $35(6)$ & $46 \quad(9)$ & 77 (18) \\
\hline \multirow{4}{*}{ Barnsley .. } & \multirow{4}{*}{. } & \multirow{4}{*}{. } & $15-19$ & $0 \quad(0)$ & $1(0)$ & 1 (1) & $0 \quad(0)$ & $3(10)$ & 1 (1) & (1) \\
\hline & & & $20-24$ & $5(0)$ & $3(0)$ & 5 (1) & $6(1)$ & $29 \quad(6)$ & $12(3)$ & 10 \\
\hline & & & 25 and Over & $5(1)$ & $15 \quad(4)$ & $16(2)$ & $33 \quad(5)$ & $55 \quad(8)$ & $27 \quad(4)$ & 12 \\
\hline & & & Total .. & $10(1)$ & 19 (4) & $22(4)$ & $39 \quad(6)$ & $87(24)$ & $40 \quad(8)$ & $22 \quad(6)$ \\
\hline \multirow{4}{*}{ Doncaster } & \multirow{4}{*}{. } & \multirow{4}{*}{$\cdots$} & $15-19$ & 1 (2) & $0 \quad(4)$ & 3 (1) & $2(2)$ & $6(2)$ & $10(14)$ & $6 \quad(10)$ \\
\hline & & & $20-24$ & $12(4)$ & $11(1)$ & $12(7)$ & $12(3)$ & $50(16)$ & $57(24)$ & 18 \\
\hline & & & 25 and Over & $52(15)$ & 44 (17) & $46 \quad(5)$ & $51(11)$ & $110(28)$ & $96(24)$ & $47 \quad(11)$ \\
\hline & & & Total .. & $65(21)$ & $55(22)$ & $61(13)$ & $65(16)$ & $166(46)$ & $163(62)$ & $71 \quad(30)$ \\
\hline
\end{tabular}

TABLE IV

PERCENTAGE FAII.URE AND RE-INFECTION RATES, BY FORM OF TREATMENT IN USE-MALES ONLY

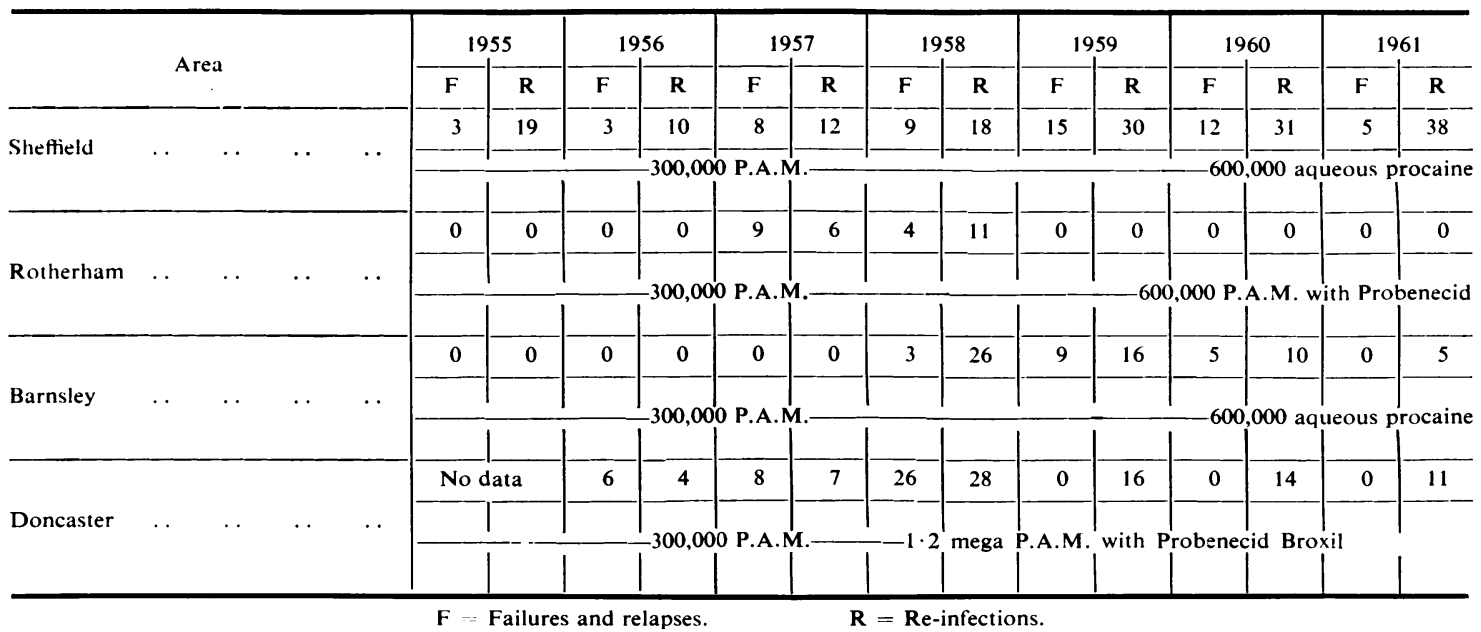

It is apparent (Table IV) that the rising failure rates eventually dictated an increased dosage of penicillin in all clinics and that this was followed by a reversal of the trend, i.e. the clinical failure rates fell everywhere.

There has been a marked fall too in the in vitro 
which receives specimens from adjacent parts of the West Riding of Yorkshire, reports a similar trend.

It is interesting to note how, once therapeutic control is inaugurated, the percentage of relatively insensitive strains is rapidly reduced.

\section{Discussion}

As elsewhere (King, 1958), the rises in gonorrhoea in the areas described are inseparably associated with increasing immigration, and to a less extent with promiscuity, most noticeable among teenage females, and with a rising incidence of relatively resistant strains of gonococci.

This study also shows that, where an immigrant population diminishes, the local infection rates fall, and that this is reflected in the proportion of teenage females infected. Furthermore, it has been shown that in the face of an increasing percentage of relatively insensitive strains an increase in routine penicillin dosage is accompanied by a fall in the percentage of failures and relapses. Clinical control is paralleled by a fall in the percentage of relatively insensitive strains found in the laboratory. Such treatment has played a part in the fall in total infections in Barnsley and Doncaster, but its value has been swamped by the rising immigration in Sheffield and Rotherham. The influence of other factors at work, e.g. the Street Offences Bill, is not yet clear.

\section{Summary and Conclusion}

The study of an epidemic of gonorrhoea in four clinic areas confirms the view that the factors at work are immigration, promiscuity, and a high percentage of relatively insensitive strains of gonococci. The last can be controlled by adequate treatment with penicillin. As the influence and incidence of immigration and the relative insensitivity of gonococci diminish, the gonorrhoea rates fall.

\section{REFERENCES}

Hilton, A. L. (1959). Brit. J. vener. Dis., 35, 249. (1961). Ibid., 37, 207.

King, A. J. (1958). Lancet, $1,651$.

Little, L. A. (1962). Personal communication.

Medical Research Council Report (1961). Lancet, 2, 226.

Epidémiologie de la blennorragie RÉSUMÉ

Une enquête sur la blennorragie dans les cliniques antivénériennes de quatre régions d'Angleterre confirme que l'augmentation de cette maladie est due aux faits suivants: l'immigration, la promiscuité, et le développement des souches gonococciques résistantes à la pénicilline.

Celle-ci peut être contrôlée par l'administration de doses adéquates de pénicilline.

La diminution de l'incidence de la blennorragie dépend de la diminution de l'immigration et des souches résistantes. 